\title{
JOURNAL.RU
}

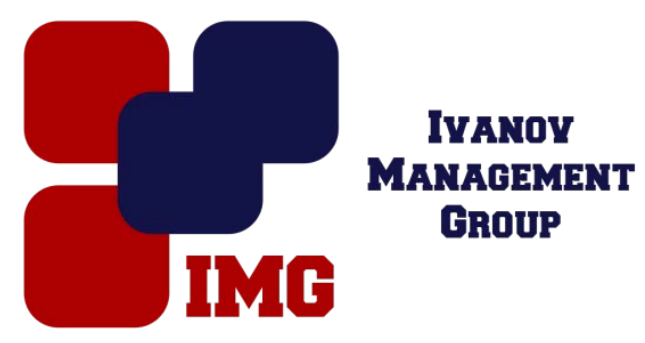

Акбашева Д.М., Алиева 3.Р., Караходжаева С.С. Северо-Кавказская государственная гуманитарно технологическая академия Черкесск, Россия

doi: 10.18411/lj-30-04-2017-1-01

idsp 000001:lj-30-04-2017-1-01

\section{Развитие агропромышленного комплекса в КЧР}

Агропромышленный комплекс Карачаево-Черкесской Республики в период времени с 2011 по 2016 годы проявляет устойчивую тенденцию роста объемов производства. Валовый объем производства продукции сельского хозяйства вырос с 19 млрд. рублей в 2012 году до 32,3 млрд. рублей по итогам 2016 года.

За последние годы в республике собраны рекордные урожаи зерновых. При этом доля продовольственного зерна составляет более $70 \%$. Это один из самых лучших результатов.

Индекс производства в прошлом году по отношению к 2014 году составил по растениеводству $112,3 \%$.

По технической и технологической модернизации сельского хозяйства ежегодно приобретается более 150 единиц техники. Отрасль растениеводства республики имеет достаточный потенциал для дальнейшего увеличения производства продукции в 2016 году. В республике возобновилось выращивание семян кукурузы, в этих целях в ООО «Хаммер» завершается строительство селекционно-семеноводческого центра.

Впервые у товаропроизводителей республики появилась возможность получить субсидию за выращивание элитных семян картофеля и овощей, при условии соблюдения требования технологии.

Карачаево-Черкесская Республика касательно сельскохозяйственного производства считается практически самодостаточной и независимой от поставок продуктов питания импортного производства. В среднем на душу 
населения по республике производится больше среднероссийских показателей по молоку, мясу, яйцу, картофелю, яйцам.

Существенно повлияло на развитие отрасли животноводства реализация Государственной программы развития сельского хозяйства и регулирования рынков сельскохозяйственной продукции, сырья и продовольствия Российской Федерации до 2020 года, и республиканской целевой программы «Развитие сельского хозяйства в Карачаево-Черкесской Республике до 2020 года».

В целях ускоренного развития животноводства в республике разработаны и исполняются программы по развития молочного и мясного скотоводства. В качестве исполнителей вышеобозначенных программ задействовано более 120 сельскохозяйственных товаропроизводителей различных категорий, в республику завезено более 5500 голов телок и нетелей молочных и мясных пород скота, создано более 1200 новых рабочих мест, построено более 20 новых и реконструировано имеющихся животноводческих помещений.

Организован прием и переработка крупного рогатого скота в трех мясоперерабатывающих предприятиях республики.

На базе первых участников РЦП по мясному скотоводству уже созданы 6 племенных репродукторов по разведению крупного рогатого скота Абердинангусской породы, в которых содержатся 1950 голов маточного поголовья.

В республике также разработана и реализуется ведомственная целевая программа «Развитие кролиководства в Карачаево-0Черкесской Республике на 2013-2015». Для реализации программы создано кролиководческое хозяйство ООО «Полюс». Проектная мощность предприятия - 12 тысяч голов маточного поголовья, выход на проектную мощность - 2016 год, годовое производство диетического мяса - 900 тонн.

В целях поддержки развития малых форм хозяйствования на селе, при активной поддержке Министерства сельского хозяйства РФ, с 2012 года осуществляется реализация мероприятий по поддержке начинающих фермеров и развитию семейных животноводческих ферм.

Так, в период с 2012-2016 гг. 967 глав крестьянских (фермерских) хозяйств стали обладателями грантов по программам поддержки начинающих фермеров и развитию семейных животноводческих ферм.

Также в Карачаево-Черкесской республике по федеральной целевой программе «Устойчивое развитие сельских территорий на 2014-2017 и на период до 2020 года» оказана помощь в приобретении и строительстве 30 тыс. кв. метров жилья. В результате чего, улучшили свои жилищные условия 248 семья, 
в том числе 118 молодые семья. По развитию социальной инфраструктуры в сельской местности, введено в эксплуатацию 212 км газовых сетей и более 150 локальных водопроводов, 14 учреждений первичной медико-санитарной помощи, 4,5 тыс. кв. метров плоскостных спортивных сооружений, представлен грант на поддержку местных инициатив граждан на селе. Также ведется строительство школы на 260 мест в с. Холоднородниковское Прикубанского района.

Предприятия пищевой и перерабатывающей промышленности КарачаевоЧеркесской Республики с каждым годом расширяют ассортимент выпускаемой продукции, осваивают новые технологии, что позволяет повышать качество продукции.

В 2016 году предприятия пищевой и перерабатывающей промышленности, такие как ОАО РАПП «Кавказ-мясо», ООО «Черкесскхлеб», ООО «Молоко», ОАО ФХ «Фирма Сатурн» продолжают наращивать производственные мощности и увеличивать производство выпускаемой продукции на 15-20\%.

В рамках государственной программы «Развитие сельского хозяйства Карачаево-Черкесской Республики до 2020 года», доля обеспечения перерабатывающих предприятий стабильной сырьевой базой, в КарачаевоЧеркесской Республике было построено 5 молокоприёмных пунктов.

\section{Литература}

1. Экономика отраслей АПК ./ Под ред. Минакова И.А. - М.: Колос, 2004.

2. Kchr.ru 